\title{
Influence of long-term heating on the fatigue properties of low-alloyed cast steel STN 422707
}

\author{
Otakar Bokůvka ${ }^{1}$, Michal Jambor ${ }^{2}$, František Nový $^{3}$, Libor Trško ${ }^{4}$, Ján Lago $^{5}$ \\ ${ }^{1}$ Prof. Ing. PhD., University of Žilina, Department of Materials Engineering, SK, phone: +421415132603 , e-mail: ota- \\ kar.bokuvka@fstroj.uniza.sk \\ ${ }^{2}$ Ing., University of Žilina, Department of Materials Engineering, SK, phone: +421415132624 , e-mail: michal.jambor@ fstroj.uniza.sk \\ ${ }^{3}$ Ing. PhD., University of Žilina, Department of Materials Engineering and Research Centre of University of Žilina, SK, \\ phone: +421415132607, e-mail: frantisek.novy@ fstroj.uniza.sk \\ ${ }^{4}$ Ing., PhD., Research Centre of the University of Žilina, SK, phone: +421415137629 , e-mail: libor.trsko@rc.uniza.sk \\ ${ }^{5}$ Ing., University of Žilina, Department of Materials Engineering, SK, phone: +421415132624, e-mail: jan.lago@ fstroj.uniza.sk
}

\begin{abstract}
In this paper the authors publish own experimental results of examination of low-alloyed cast steel STN 422707 fatigue properties (near- threshold regime of fatigue crack propagation for rates from da/ $/ \mathrm{dN}=5.6 \times 10^{-9} \mathrm{~m} \cdot \mathrm{cycle}^{-1}$ to da $/ \mathrm{dN}=10^{-12} \mathrm{~m} \cdot \mathrm{cycle} \mathrm{e}^{-1}$ and $\mathrm{K}_{\mathrm{ath}}$ at da/ $/ \mathrm{dN}=10^{-}$ ${ }^{12}$ m.cycle $\left.^{-1}\right)$ initial state and after long-term heating $\left(\mathrm{T}=400{ }^{\circ} \mathrm{C}, \mathrm{t}=4000\right.$ hours $\approx 167$ days $)$ obtained at high-frequency loading $(\mathrm{f} \approx 20 \mathrm{kHz}, \mathrm{T}$ $\left.=20 \pm 5{ }^{\circ} \mathrm{C}, \mathrm{R}=-1\right)$. The long-term heating of material caused decrease of $\mathrm{K}_{\mathrm{ath}}$ and increase of fatigue crack growth rate in the near-threshold regime; then worse of low-alloyed cast steel STN 422707 fatigue properties.
\end{abstract}

Key words- cast steel STN 422707 , long-term heating, fatigue properties, $\mathrm{K}_{\mathrm{ath}}$, da/dN = $\mathrm{f}\left(\mathrm{K}_{\mathrm{a}}\right)$

\section{Introduction}

Fatigue is a predominating fracture mode of components and constructions. Therefore, its prevention is a fundamental design criterion (BOKŮVKA O. et al. 2002, UlewiCZ R., MAZUR M. 2013). Lifetime of components or constructions (number of cycles $\mathrm{N}$ ) contains number of cycles necessary for fatigue crack nucleation $\mathrm{N}_{\mathrm{i}}$ and number of cycles for crack propagation $\mathrm{N}_{\mathrm{s}}$. Components or constructions in terms of their resistance to fatigue failure can be evaluated by two methods; that is according to total lifetime (number of cycles $\mathrm{N}$, where $\mathrm{N}=\mathrm{N}_{\mathrm{i}}+\mathrm{N}_{\mathrm{s}}$ ) or according to fatigue crack propagation with respect to laws of fracture me- chanics (according to number of cycles necessary for crack propagation $\mathrm{N}_{\mathrm{s}}$ ) (TRŠKO L. et al. 2013, SKOČOVSKÝ P. et al. 2015).Evaluation of components and constructions resistance according to fatigue crack propagation describes well the real state, because the most of operation fractures is caused by fatigue crack growth from defects of different character. Amplitude of stress intensity factor $\mathrm{K}_{\mathrm{a}}$ is the determining characteristic for describing fatigue crack propagation. In this case for evaluation of material fatigue properties is used experimentally obtained fatigue crack growth curve that is dependenton the rate of fatigue crack growth $\mathrm{da} / \mathrm{dN}$ on the amplitude of stress intensity factor $K_{a}$ and where the $K_{a t h}$ is basic threshold 
value of amplitude of stress intensity factor $K_{a}$.In this curve there can be observed the near-threshold regime $\left(\mathrm{da} / \mathrm{dN}<10^{-9} \mathrm{~m} \cdot \mathrm{cycle}^{-1}\right.$, mid-growth rate regime $(\mathrm{da} / \mathrm{dN}$ $=10^{-9}$ m.cycle ${ }^{-1} \div 10^{-6}$ m.cycle $\left.{ }^{-1}\right)$ and high-growth rate regime $\left(\mathrm{da} / \mathrm{dN}>10^{-6} \mathrm{~m} \cdot \mathrm{cycle}^{-1}\right)$. The behaviour in the near-threshold regime is very influenced by structure, environment, value of $\sigma_{\mathrm{m}}$, mechanical properties incl. toughness temperature and value of asymmetry coefficient R (KUNZ L. 2003, RITCHIE R. O. 1981, BOKUீVKA O. et al. 2015).

Cast steels are very important group of construction materials. With regard to the chemical composition and structure, in principle, there are no differences from wrought steel. However, in cast steelcasting defects (buckles, shrinkages, cavities, blowholes and so on) resultingfrom casting procedure are observed (LETKO I. et al. 2002, SKOČOVSKÝ P. et al. 2000). These defects are preferred places for the fatigue crack growth (LETKO I. et al. 2002, KLESNIL M., LUKÁŠ P. 1975, HuRTALOVÁ L. et al. 2013).

In this paper the authors publish own experimental resultsof examination of low-alloyed cast steel STN 42 2707 fatigue properties (near-threshold regime incl. $\mathrm{K}_{\text {ath }}$ ), initial state and after long-term heating, obtained at high-frequency loading ( $\mathrm{f}=20 \mathrm{kHz}, \mathrm{T}=20 \pm 5^{\circ} \mathrm{C}$, $\mathrm{R}=-1)$.

\section{Experimental part}

The experimental work, quantitative chemical analysis, optical light microscopy, tensile tests and fatigue tests were carried out on two different states (initial and after long-term heating) of low-alloyed cast steel STN 42 2707. Chemical analysis was performed by the emission spectrometry on an ICP (JY 385) emission spectrometer using a fast recording system Image. A light metallographic microscope AXIO Imager A1m was used for metallography analysis. Tensile tests were carried out on a ZWICK Z050 testing machine at ambient temperature of $\mathrm{T}=20 \pm 5^{\circ} \mathrm{C}$, with the loading range in interval $\mathrm{F}=0 \div 20 \mathrm{kN}$ and the strain rate $\varepsilon_{\mathrm{m}}=10^{-3} \mathrm{~s}^{-1}$. Round cross-section specimens were used; the shape and dimensions of the test specimens met the requirements of EN 10002-1 standard (5 specimens were used). Fatigue tests were carried out at high-frequency sinusoidal cyclic tension-compression loading ( $\mathrm{f}=20 \mathrm{kHz}, \mathrm{T}=20 \pm 5{ }^{\circ} \mathrm{C}, \mathrm{R}=-1$, cooled by distilled water with anticorrosive inhibitor) and with the use of high-frequency loading equipment KAUP-ZU Žilina (BOKŮVKA O. et al. 2015, PUŠKÁR A. et al. 1987, TRŠKO L. et al. 2016).

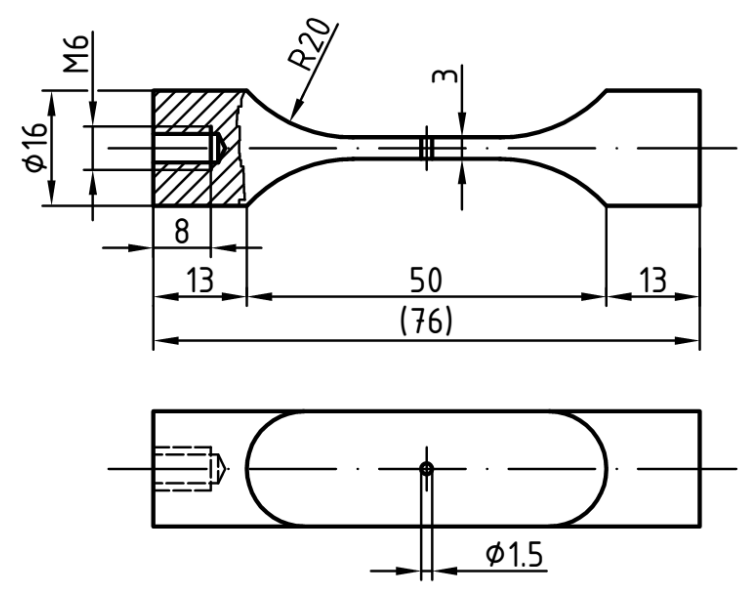

Fig.1. The shape and dimensions of the fatigue crack growth test specimen

Source: own study

The shape and dimensions of specimens used in the fatigue crack growth tests are given in Fig. 1. The applied amplitude of stress intensity factor $\mathrm{K}_{\mathrm{a}}$ was determined using the following equation:

$$
K_{a}=\sigma_{a} \cdot\left(w \cdot \operatorname{tang}\left(\frac{\pi \cdot a}{w}\right)\right)^{1 / 2} \quad \mathrm{MPa}^{1 / 2}
$$

in which $\sigma_{\mathrm{a}}$ is stress amplitude (MPa), a is the half crack length $(\mathrm{m})$ and $\mathrm{W}$ is the specimen width $(\mathrm{m})$, (BOKU゚VKA O. et al. 2015, PUŠKÁR A. et al. 1987, TRŠKO L. et al. 2016). The fatigue crack growth rate $\mathrm{da} / \mathrm{dN}=\mathrm{f}\left(\mathrm{K}_{\mathrm{a}}\right)$ in the area from $\mathrm{da} / \mathrm{dN}=5.6 \times 10^{-9}$ m.cycle ${ }^{-1}$ to da/dN $=10^{-12}$ m.cycle ${ }^{-1}$ and the value of $K_{\text {ath }}$ was determined at $\mathrm{da} / \mathrm{dN}=10^{-12} \mathrm{~m}^{-c y c l e^{-1}}$; four specimens of initial state of low-alloyed cast iron and the four specimens after long-term heating $\left(\mathrm{T}=400{ }^{\circ} \mathrm{C}, \mathrm{t}=\right.$ 4000 hours $(\approx 167$ days $)$ in the furnace with protective atmosphere) were used.

\section{Results and discussions}

The results of quantitative chemical analysis (chemical composition), tensile tests (yield point $\mathrm{R}_{\mathrm{p}} 0,2$ tensile strength $R_{m}$, elongation $A_{5}$, reduction of area $Z$, toughness $\mathrm{KCV}^{+23}$ ), optical light microscopy (microstructure) and high-frequency fatigue tests $(\mathrm{da} / \mathrm{dN}=$ 
$\left.\left.\mathrm{f}\left(\mathrm{K}_{\mathrm{a}}\right), \mathrm{K}_{\text {ath }}\right)\right)$ are shown in Table 1, Table 2, Table 3 and on the Fig. 2 and Fig. 3.

Table 1. Chemical composition (in weight \%), low-alloyed cast steel STN 422707

\begin{tabular}{|c|c|c|c|c|c|c|c|c|c|}
\hline $\begin{array}{c}\text { Cast steel } \\
\text { STN } 42 \\
2707\end{array}$ & $\begin{array}{c}\mathrm{C} \\
\max .\end{array}$ & $\mathrm{Si}$ & Mn $\underset{\max }{\mathrm{P}}$ & $\begin{array}{c}\mathrm{S} \\
\max .\end{array}$ & $\begin{array}{c}\mathrm{Cr} \\
\max .\end{array}$ & $\begin{array}{c}\mathrm{Ni} \\
\max .\end{array}$ & $\begin{array}{l}\text { Mo } \\
\text { max. }\end{array}$ & $\begin{array}{l}\text { Co } \\
\max .\end{array}$ & $\begin{array}{c}\mathrm{Al} \\
\max .\end{array}$ \\
\hline standard & 0.12 & $\begin{array}{l}0.2 \\
0.5\end{array}$ & $\begin{array}{ll}1.0 & 0.025 \\
1.6 & \end{array}$ & 0.020 & 0.3 & 0.4 & 0.15 & 0.30 & - \\
\hline verified & 0.1 & 0.31 & 1.450 .019 & 0.016 & 0.09 & 0.08 & - & 0.12 & 0.08 \\
\hline
\end{tabular}

Source: own study

Table 2. Mechanical properties of low-alloyed cast steel STN 422707

\begin{tabular}{c|ccccc}
\hline $\begin{array}{c}\text { Cast steel } \\
\text { STN }\end{array}$ & $\begin{array}{c}\mathrm{R}_{\mathrm{p} 0.2} \\
(\mathrm{MPa})\end{array}$ & $\begin{array}{c}\mathrm{R}_{\mathrm{m}} \\
(\mathrm{MPa})\end{array}$ & $\begin{array}{c}\mathrm{A}_{5} \\
(\%)\end{array}$ & $\begin{array}{c}\mathrm{Z} \\
(\%)\end{array}$ & $\begin{array}{c}\mathrm{KCV}^{+23} \\
\left(\mathrm{~J} . \mathrm{cm}^{-2}\right)\end{array}$ \\
\cline { 2 - 6 } & 285 & 464 & 39.1 & 71.8 & 158.8 \\
\hline
\end{tabular}

Source: own study

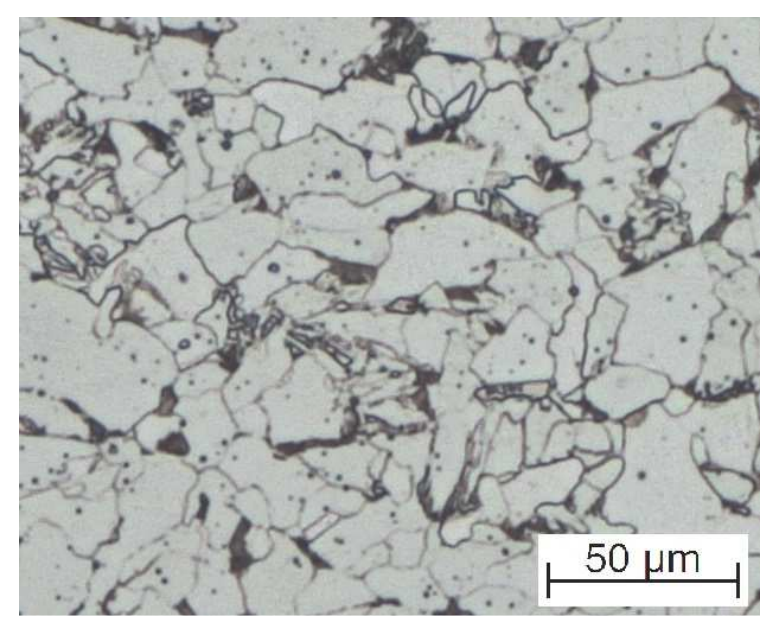

Fig. 2 Microstructure of low-alloyed cast steel STN 42 2707, etch. $3 \%$ Nital

Source: own study

Table 3. Basic threshold values of amplitude of stress intensity factor $K_{\text {ath }}$, low-alloyed cast steel STN 42 2707, initial state (A) and after long-term heating $(B)$, high frequency fatigue loading $\left(f=20 \mathrm{kHz}, T=20 \pm 5^{\circ} \mathrm{C}, R=-1\right)$

\begin{tabular}{|c|c|c|c|c|}
\hline $\begin{array}{l}\text { Number of } \\
\text { specimen }\end{array}$ & $\mathrm{A}_{1}$ & $\mathrm{~A}_{2}$ & $\mathrm{~A}_{3}$ & $\mathrm{~A}_{4}$ \\
\hline $\begin{array}{c}\mathrm{K}_{\text {ath }} \\
\left(\mathrm{MPa} \cdot \mathrm{m}^{1 / 2}\right)\end{array}$ & 5.23 & 5.03 & 5.16 & 5.15 \\
\hline \multicolumn{5}{|c|}{ Average value of $\mathrm{K}_{\mathrm{ath}} 1 \div 4=5.14 \mathrm{MPa} \cdot \mathrm{m}^{1 / 2}$} \\
\hline $\begin{array}{c}\text { Number of } \\
\text { specimen }\end{array}$ & $\mathrm{B}_{1}$ & $\mathrm{~B}_{2}$ & $\mathrm{~B}_{3}$ & $\mathrm{~B}_{4}$ \\
\hline $\begin{array}{c}\mathrm{K}_{\mathrm{ath}} \\
\left(\mathrm{MPa} \cdot \mathrm{m}^{1 / 2}\right)\end{array}$ & 54.58 & 4.57 & 4.53 & 4.18 \\
\hline \multicolumn{5}{|c|}{ Average value of $\mathrm{K}_{\mathrm{ath}} 1 \div 4=4.46 \mathrm{MPa} \cdot \mathrm{m}^{1 / 2}$} \\
\hline
\end{tabular}

Source: own study

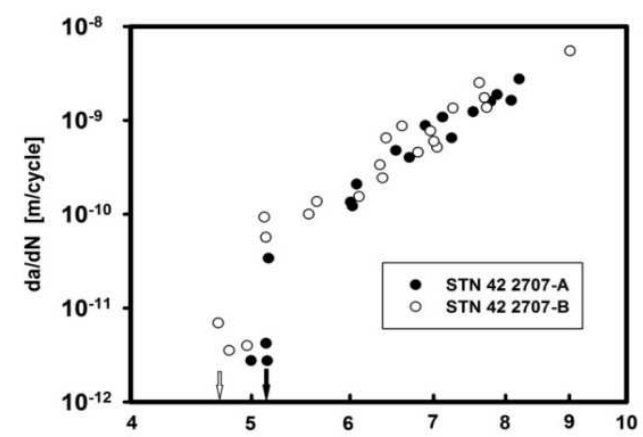

Fig. 3. Dependence of fatigue crack growth rate da/dN on the amplitude of stress intensity factor $K_{a}, d a / d N=f\left(K_{a}\right)$, low-alloyed cast steel STN 42 2707, high frequency fatigue loading ( $f=20$ $k H z, T=20 \pm 5^{\circ} \mathrm{C}, R=-1$ )

Source: own study

The chemical composition and mechanical properties of tested material, Table 1, 2 correspond with STN 422707 standard. The microstructure (Fig. 2) was created by ferrite and perlite and is characteristic for cast steel.

The obtained results about fatigue resistance of low-alloyed cast steel STN 422707 are shown in Table 3 and on the Fig. 3. The basic amplitudes of stress intensity factor $\mathrm{K}_{\mathrm{ath}}$ were $\mathrm{K}_{\mathrm{ath}}=5.14 \mathrm{MPa} \cdot \mathrm{m}^{1 / 2}$ (initial state A) and $\mathrm{K}_{\mathrm{ath}}=4.46 \mathrm{MPa} \cdot \mathrm{m}^{1 / 2}$ (state after long-term heating, B); decrease (B) against (A) state is cca 13.2 $\%$. We can calculate the critical size of crack $a_{c}$ (permissible size of defect) with using equation (2), where

$$
a_{c}=\frac{1}{\pi} \cdot\left(\frac{K_{a t h}}{\sigma_{s}}\right)^{2} \mathrm{~m}
$$

$\mathrm{K}_{\text {ath }}$ is basic threshold value of amplitude of stress intensity factor $\left(\mathrm{MPa}^{1 / 2}\right)$ and $\sigma_{\mathrm{s}}$ the safe stress $(\mathrm{MPa}) ; \sigma_{\mathrm{s}}=80 \mathrm{MPa}$ and is valid in the power industry for water pumps design. The critical size of defect is $a_{c}$ $=1.31 \mathrm{~mm}$ (for initial state, $\mathrm{A}$ ) and $\mathrm{a}_{\mathrm{c}}=0.98 \mathrm{~mm}$ (for state after long-term heating, B); decrease of this value for heat threated state against value for initial state is cca $25.2 \%$. These factscorrespond with works (BOKU゚VKA O. et al. 2002, BOKUீVKA O. et al. 2015). The value of $K_{\text {ath }}$ for initial state (Table 3) was $K_{\text {ath }}=$ $5.14 \mathrm{MPa}^{1 / 2}$. The authors (RŮŽIČKOVÁ M. et al. 1999 ) in their study based on their own results (19 th wrought steels with $\mathrm{Rm}$ from $\mathrm{R}_{\mathrm{m}}=360 \mathrm{MPa}$ to $\mathrm{R}_{\mathrm{m}}=$ $1820 \mathrm{MPa}$ ) suggested equation for $\mathrm{K}_{\mathrm{ath}}$ calculation (3),

$$
K_{a t h}=-0.0052 R m+8.5906 \quad \mathrm{MPa}^{1 / 2}
$$
where $\mathrm{R}_{\mathrm{m}}$ is tensilestrength [MPa]. This equation is valid in the region from $\mathrm{R}_{\mathrm{m}} \approx 360 \mathrm{MPa}$ to $\mathrm{R}_{\mathrm{m}} \approx 1040$ 
$\mathrm{MPa}$, after $\mathrm{R}_{\mathrm{m}} \approx 1040 \mathrm{MPa}$ the $\mathrm{K}_{\mathrm{ath}}$ is constant, $\mathrm{K}_{\mathrm{ath}}=$ $3.21 \mathrm{MPa} \cdot \mathrm{m}^{1 / 2}$. With using equation (3) the value of $\mathrm{K}_{\mathrm{ath}}=6.17 \mathrm{MPa} \cdot \mathrm{m}^{1 / 2}$. The experimentally determined value of $\mathrm{K}_{\text {ath }}$ in the case of low-alloyed cast steel STN 422707 is lower.

The obtained results mentioned above confirm the conclusions about a considerable influence of different factors(e. g. structure, temperature, mechanical properties incl. toughness) on the fatigue resistance of structural materials in the near-threshold regime (TRŠKO L. et al. 2013, RITCHIE R. O. 1981,BOKU゚VKA O. et al. 2015).

The results (Fig. 3) after da/dN $=10^{-10} \mathrm{~m}^{-c y c l e}{ }^{-1}$ are for the both state (initial and state after long-term heating), is practically the same. It corresponds with works (KUNZ L. 2003, RITCHIE R. O. 1981,BOKŮVKA O. et. al. 2015, TRŠKO L. et al. 2016) which stated small influence of structure, temperature, mechanical properties incl. toughness, $\sigma_{\mathrm{m}}$, and enviroment on the dependence of rate of fatigue crack growth da/dN vs. amplitude of stress intensity factor $K_{a}$ in the midgrowth rate regime.

With regard to the results, it can be assumed that ageing is the reason of fatigue resistance decrease. This effect is observed very often in the mild steels. The aging is the reason for changes of material strength and deformation properties. The tensile strength, yield point, hardness increase but, on the other hand, the elongation and toughness decrease. The size of plastic zone on the crack tip decrease. With regard to this fact, the retardation effect against fatigue crack growth decrease and therefore decrease the value of $K_{\text {ath }}$ (PÍŠEK F. et al. 1975).

\section{Conclusions}

With reference to the experimental results carried out at high-frequency loading ( $\mathrm{f}=20 \mathrm{kHz}, \mathrm{T}=20 \pm$ $5{ }^{\circ} \mathrm{C}, \mathrm{R}=-1$ ) the following can be summed up:

- in the low-alloyed cast steel STN 422707 was recorded negative influence of long-term heating ( $\mathrm{T}=400{ }^{\circ} \mathrm{C}, \mathrm{t}=167$ days) on her fatigue resistance in the near-threshold regime;

- the basic threshold value amplitude of stress intensity factor $K_{a t h}$ due to long-term heating decrease cca $13.2 \%$ (initial state $\mathrm{K}_{\text {ath }}=5.14 \mathrm{MPa} \cdot \mathrm{m}^{1}$; state after long-term heating, $\mathrm{K}_{\mathrm{ath}}=4.46 \mathrm{MPa} \cdot \mathrm{m}^{1 / 2}$ );

- the critical defect size decreasecca $25.2 \%$ (initial state, $a_{c}=1.31 \mathrm{~mm}$; state after long-term heating, $\mathrm{a}_{\mathrm{c}}=0.98 \mathrm{~mm}$ );
- in the mid-growth regime of $\mathrm{da} / \mathrm{dN}=\mathrm{f}\left(\mathrm{K}_{\mathrm{a}}\right)$ curve was not recorded differences in fatigue behavior;

- these facts must be taken in consideration with reference to reliability and safety when designing the structural elements.

\section{Acknowledgements}

The research was supported by Scientific Grand Agency of Ministry of Education, Science and Sport of Slovak Republic and Slovak Academy of Sciences, grant VEGA No. 1/0123/15, by the project APVV-140096 and project "Research Centre of the University of Žilina", ITMS 26220220183.

\section{Bibliography}

1. BOKUீVKA O. et al. 2002. Low and High Frequency Fatigue Testing. EDIS ŽU v Žiline.

2. UlewicZ R., MAZUR M. 2013. Production Engineering Archives, No. 1, 32.

3. TRŠKo L. et al. 2013. Dynamics Strength and Fatigue Lifetime. EDIS ŽU v Žiline.

4. SKoČOvsKÝ P. et al. 2015. Náuka o materiáli. EDIS ŽU v Žiline (in Slovak).

5. KunZ L. 2003. Experimentální stanoveníu na vových charakteristik materiálů. EDIS ŽU v Žiline (in Czech).

6. RITCHIE R.O. 1981. Application of Fracture Mechanics to Fatigue Crack Propagation. University of California.

7. LetKo I. et al. 2002. Priemyselné technológie II. EDIS ŽU v Žiline (in Slovak).

8. SKOČOVsKÝ, P. et al. 2000. Konštrukčné materiály. EDIS ŽU v Žiline (in Slovak).

9. KLESNIL M., LUKÁŠ P. 1975. Únavakovových materiál ůpři mechanickémnamáhání. ACADEMIA Praha (in Czech).

10. HuRtalová L. et al. 2013. Key Eng. Materials, Vol. 592-593, 433.

11. BOKUீVKA O. et al. 2015. Fatigue of Materials at Low and High-frequency Loading. EDIS ŽU v Žiline.

12. PUŠKÁR A. et al. 1987. Strojírenství, 2, 507 (in Slovak).

13. TRŠKO L. et al. 2016. Production Engineering Archives, Vol. 10 (1).

14. RƯŽIČKOVÁ M. et al. 1999. Materiálové inžinierstvo, 6, 19 (in Slovak).

15. PÍŠEK F. et al. 1975. Nauka o materiálu I., 4. svazek. ČAV Praha (in Czech). 